\title{
Engineering pyruvate decarboxylase-mediated ethanol production in the thermophilic host Geobacillus thermoglucosidasius
}

\author{
L. J. Van Zyl, M. P. Taylor, K. Eley, M. Tuffin and D. A. Cowan
}

\begin{abstract}
This study reports the expression, purification, and kinetic characterization of a pyruvate decarboxylase (PDC) from Gluconobacter oxydans . Kinetic analyses showed the enzyme to have high affinity for pyruvate (120 $\mu \mathrm{M}$ at $\mathrm{pH} 5)$, high catalytic efficiency $\left(4.75 \times 10^{5} \mathrm{M}^{-1} \mathrm{~s}^{-1}\right.$ at $\mathrm{pH}$ 5), a pHopt of approximately 4.5 and an in vitro temperature optimum at approximately $55{ }^{\circ} \mathrm{C}$. Due to in vitro thermostablity (approximately $40 \%$ enzyme activity retained after $30 \mathrm{~min}$ at $65{ }^{\circ} \mathrm{C}$ ), this PDC was considered to be a suitable candidate for heterologous expression in the thermophile Geobacillus thermoglucosidasius for ethanol production. Initial studies using a variety of methods failed to detect activity at any growth temperature $\left(45-55^{\circ} \mathrm{C}\right)$. However, the application of codon harmonization (i.e., mimicry of the heterogeneous host's transcription and translational rhythm) yielded a protein that was fully functional in the thermophilic strain at $45^{\circ} \mathrm{C}$ (as determined by enzyme activity, Western blot, mRNA detection, and ethanol productivity). Here, we describe the first successful expression of PDC in a true thermophile. Yields as high as $0.35 \pm 0.04 \mathrm{~g} / \mathrm{g}$ ethanol per gram of glucose consumed were detected, highly competitive to those reported in ethanologenic thermophilic mutants. Although activities could not be detected at temperatures approaching the growth optimum for the strain, this study highlights the possibility that previously unsuccessful expression of pdes in Geobacillus spp. may be the result of ineffective transcription/translation coupling.
\end{abstract}

\section{Introduction}

Pyruvate decarboxylase (PDC, EC 4.1.1.1) is responsible for the non-oxidative decarboxylation of pyruvate to acetaldehyde and carbon dioxide. PDCs are common in the plant and fungal kingdoms and at least in the latter, together with alcohol dehydrogenase (ADH, EC 1.1.1.1) form part of an ethanol fermentation pathway (Konig et al. 1998). Several plant and yeast PDCs have been isolated and characterized, but as yet only four of bacterial origin has been described- from Zymomonas mobilis, Zymobacter palmae, Acetobacter pasteurianus, and Sarcina ventriculi (Raj et al. 2002). Bacterial PDCs participate in ethanol production via the Entner- Doudoroff pathway and not through glycolysis for pyruvate production.

There has been an increased interest in the use of thermophiles, such as Geobacillus thermoglucosidasius, for ethanol production, primarily because of their catabolic promiscuity, an important benefit for a second-generation bioprocess design (Cripps et al. 2009; Taylor et al. 2009). Other advantages include improved product removal, reduced incidence of 
contamination, and high ethanol yields in selectively mutated strains (Taylor et al. 2009). Ethanol production in G. thermoglucosidasius and mutants with enhanced ethanologenic phenotypes relies on endogenous metabolic pathways, generating acetyl CoA via pyruvate dehydrogenase and its subsequent conversion to acetaldehyde and ethanol by aldehyde dehydrogenase and alcohol dehydrogenase, respectively (Cripps et al. 2009). An alternative to further develop G. thermoglucosidasius as an ethanologenic strain is to engineer the expression of the PDC pathway. The in vitro high specificity and thermostability (half-life of 30 min at $60{ }^{\circ} \mathrm{C}$ ) of the $\mathrm{Z}$. mobilis PDC (ZmoPDC) has made it the main candidate for such engineering (Pohl et al. 1995). However, both the ZmoPDC and Z. palmae PDC (ZpaPDC) have been expressed in G. thermoglucosidasius but do not function at temperatures exceeding 55 ${ }^{\circ} \mathrm{C}$, despite good in vitro thermostability at these temperatures. The reasons for the low levels of activity are not fully understood (Taylor et al. 2008; Thompson et al. 2008), but protein misfolding resulting in inactive protein has been proposed (Thompson et al. 2008). Attempts to express these proteins in mesophilic Gram-positive hosts (notably lactic acid bacteria and Bacillus megatarium ) have also had limited success (Gold et al. 1996; Bongers et al. 2005; Kaczowka et al. 2005; Talarico et al. 2005; Liu et al. 2005, 2006, 2007; Orencio-Trejo et al. 2008; Bi et al. 2009).

The role that codon usage plays in heterologous protein expression has been recognized, but is not well understood (Gustafsson et al. 2004). It has been demonstrated that the position and usage frequency of codons, together, play a role in correct protein folding and that "codon harmonization" could be used to overcome poor expression, at least in Escherichia coli (Angov et al. 2008; Rosano et al. 2009). Incompatibilities in codon usage and their effect on expression of PDCs have been reported (Talarico et al. 2001, 2005; Lowe et al. 1992). Two examples of the effect of codon usage on PDC production include the five- to tenfold increase in soluble S. ventriculi PDC (SvePDC) when expressed in an E. coli strain with or without accessory tRNAs (specifically those which are rarely used in E. coli), as well as the superior production of this PDC relative to those from A. pasteurianus and Z. mobilis in B. megatarium (Raj et al. 2002; Talarico et al. 2001, 2005).

Despite the rarity of prokaryotic PDCs, we have identified a pdc-like gene sequence in the genome sequence of a Gram-negative acetic acid bacterium, Gluconobacter oxydans . A PDC enzyme from G. oxydans has previously been characterized (King et al. 1954). G. oxydans is often associated with sugar-rich environments such as ripe fruit, honey, and cider as well as in a variety of soil types and is used industrially to produce L-sorbose from D-sorbitol, Dgluconic acid and 5- keto- and 2-ketogluconic acids from D -glucose, and dihydroxyacetone from glycerol (Gupta et al. 2001). This organism uses the PDC as part of the well-characterized lactate oxidation and acetate excretion pathways (Raj et al. 2001; Peters et al. 2012).

The aim of this study was to evaluate the ethanologenic potential of the G. oxydans PDC (GoxPDC) expression in G. thermoglucosidasius . We report the cloning, expression, and characterization of GoxPDC as well as its "codon harmonization" for enhanced expression in this Gram-positive thermophilic host.

\section{http://repository.uwc.ac.za}




\section{Materials and methods}

\section{Media, bacterial strains, and plasmids}

Bacterial strains and plasmids used in this study are shown in Table 1. E. coli strains were grown in Luria-Bertani (LB) broth (Sambrook et al. 1989) with $200 \mu \mathrm{g} / \mathrm{ml}$ ampicillin or $50 \mu \mathrm{g} / \mathrm{ml}$ kanamyc in a d d ed as required. G. thermoglucosidasius strains were cultured either in LB, 2TY, TGP media, or modified urea sulphates medium (USM). In general, E. coli $\mathrm{DH}_{5} \alpha$ was used for plasmid construction.

One liter of TGP broth contained $17 \mathrm{~g}$ tryptone, $3 \mathrm{~g}$ soy peptone, $2.5 \mathrm{~g} \mathrm{~K}_{2} \mathrm{HPO}_{4}$, and $5 \mathrm{~g} \mathrm{NaCl}$. The $\mathrm{pH}$ was adjusted to 7.3 before autoclaving, after which $4 \mathrm{~g}$ Na-pyruvate and $4 \mathrm{~mL}$ glycerol were added in the form of filter-sterilized 10× concentrates. For solid media, $15 \mathrm{~g} / \mathrm{L}$ agar was added before autoclaving. LB and TGP were used during genetic manipulation and general maintenance of cultures.

Per liter, 2TY medium contained $10 \mathrm{~g}$ yeast extract, $5 \mathrm{~g} \mathrm{NaCl}, 20 \mathrm{~g}$ tryptone, and $15 \mathrm{~g}$ agar (where applicable), with a final $\mathrm{pH}$ of 7.0. USM supplemented with yeast extract (USMYE) contained10 g glucose, $0.42 \mathrm{~g}$ citric acid, $0.31 \mathrm{~g} \mathrm{MgSO}_{4}, 3.1 \mathrm{~g} \mathrm{NaH}_{2} \mathrm{PO}_{4}, 3.5 \mathrm{~g} \mathrm{~K}_{2} \mathrm{SO}_{4}, 3 \mathrm{~g}$ urea, $2.2 \mathrm{mg} \mathrm{CaCl}_{2}, 0.4 \mathrm{mg} \mathrm{Na}_{2} \mathrm{MoO}_{4}$, $1 \mathrm{~g}$ yeast extract, $1 \mathrm{~g}$ typtone, $8.36 \mathrm{~g}$ Bis-Tris, 12.08 $\mathrm{g}$ PIPES, $10.4 \mathrm{~g}$ HEPES, $1 \mathrm{ml}$ silicone antifoam, and $5 \mathrm{ml}$ trace elements solution per liter. The trace element solution contained(per liter) $1.44 \mathrm{gZnSO}_{4} .7 \mathrm{H}_{2} \mathrm{O}, 0.56 \mathrm{~g} \mathrm{CoSO}_{4} .6 \mathrm{H}_{2} \mathrm{O}$, 0 . $25 \mathrm{~g} \mathrm{CuSO}_{4} \cdot 5 \mathrm{H}_{2} \mathrm{O}, 5.56 \mathrm{gFeSO}_{4} \cdot 6 \mathrm{H}_{2} \mathrm{O}, 0.89 \mathrm{~g} \mathrm{NiSO}_{4} .6 \mathrm{H}_{2} \mathrm{O} ; 1.69 \mathrm{~g} \mathrm{MnSO}_{4}$, and 5.0 $\mathrm{ml} 12 \mathrm{M} \mathrm{H}_{2} \mathrm{SO}_{4}$. The trace elements solution and glucose ( $50 \mathrm{ml}$ of a $20 \% \mathrm{w} / \mathrm{v}$ solution) were added aseptically after autoclaving. The $\mathrm{pH}$ of USM was adjusted to $\mathrm{pH}$ of 7 using $10 \mathrm{M}$ $\mathrm{NaOH}$. Cultures were incubated at 45,52 , or $60^{\circ} \mathrm{C}$ as required with vigorous aeration.

G. oxydans was cultured in medium containing, per liter: $8 \mathrm{~g}$ yeast extract, $15 \mathrm{~g}$ peptone, $10 \mathrm{~g}$ glucose, $0.5 \%(\mathrm{w} / \mathrm{v})$ ethanol, and $0.3 \%(\mathrm{w} / \mathrm{v})$ acetic acid. The final $\mathrm{pH}$ was between 3.5 and 4. Ethanol, acetic acid, and glucose were added after autoclaving. Cultures were incubated at $25^{\circ} \mathrm{C}$.

\section{DNA manipulations and sequencing}

Restriction endonuclease digestion, gel electrophoresis, and ligation performed using standard methods or following the manufacturers' recommendations (Sambrook et al. 1989). Ultrapure plasmid DNA was obtained using the Wizard Plus SV miniprep DNA purification system (Promega ${ }^{\mathrm{TM}}$ ). Total DNA from all bacterial strains was prepared as described (Kotze et al. 2006). 


\begin{tabular}{|c|c|c|}
\hline Strain or plasmid & Genotype or description & Source or reference \\
\hline \multicolumn{3}{|l|}{ Strains } \\
\hline G. thermoglucosidasius TM89 & ldh $\mathrm{A}^{-}$variant of G. thermoglucosidasius NCIMB 11955 & TMO renewables \\
\hline G. oxydans (DSMZ7145) & Isolated from beer & DSMZ \\
\hline E. coli $\mathrm{DH} 5 \alpha$ & $\begin{array}{l}\mathrm{F}^{\prime} / \text { endA1 hsdR17 }\left(\mathrm{r}_{\mathrm{K}}^{-} \mathrm{m}_{\mathrm{K}}^{+}\right) \text {supE44 thi-1 reacAl gyrA }\left(\mathrm{Nal}^{\mathrm{T}}\right) \\
\quad \text { relA1 } \Delta(\text { lacZYA-argF }) U 169(\phi 80 \text { dlac } \Delta(\text { lacZ }) M 15)\end{array}$ & Promega Corp. \\
\hline E. coli BL21-DE3 & E. coli $\mathrm{B} \mathrm{F}^{-} d c m$ omp $\left.\mathrm{T} h s d \mathrm{~S}_{\left(\mathrm{B}_{\mathrm{B}}^{-}\right.}^{-} \mathrm{m}_{\mathrm{B}}^{-}\right)$gal $\lambda(\mathrm{DE} 3)$ & Invitrogen Corp. \\
\hline E. coli JM109 & $\begin{array}{l}\mathrm{F}^{\prime} \text { traD36 proA }{ }^{+} B^{+} \text {laclq } \Delta(\text { lacZ }) M 15 / \Delta(\text { lac }- \text { proAB }) \\
\text { glnV44 e14 }{ }^{-} \text {gyrA96 recAl relAl endA1 thi hsdR17 }\end{array}$ & $\begin{array}{l}\text { New England Biolabs, Beverley, } \\
\text { MA, USA }\end{array}$ \\
\hline \multicolumn{3}{|l|}{ Plasmids } \\
\hline pET28a & $\mathrm{Kan}^{\mathrm{r}}$; ColE1 replicon, HIS-tag expression vector & Novagen Corp. \\
\hline pGO & $\mathrm{Kan}^{\mathrm{r}}$; ColE1 replicon; G. oxydans pdc gene cloned into pET28a & This study \\
\hline pldhGO & $\begin{array}{l}\mathrm{Kan}^{\mathrm{r}} \text {; ColE1 replicon; lactate dehydrogenase }(\mathrm{Pldh}) \text { gene promoter } \\
\text { region }( \pm 170 \text { bp Nco } \mathrm{I}-N d e \mathrm{I}) \text { from G. thermoglucosidasius } \\
\text { NCA1503 cloned upstream of the G. oxydans pdc gene in pET28a }\end{array}$ & This study \\
\hline pTM049 & $\begin{array}{l}\text { Derivative of pUB190 containing the } l d h \text { promoter from } G \text {. } \\
\text { stearothermophilus NCA1503. }\end{array}$ & TMO Renewables (Cripps 2009) \\
\hline pTMO111 & $\begin{array}{l}\text { Amp }^{\mathrm{r}}, \operatorname{Kan}^{\mathrm{r}} \text { (in G. thermoglucosidasius) ColE1 replicon, pUB110 } \\
\text { IncA replicon, E. coli }- \text { G. thermoglucosidasius shuttle-suicide } \\
\left(>55^{\circ} \mathrm{C}\right) \text { vector containing a truncated pflB gene }\end{array}$ & TMO Renewables (Cripps 2009) \\
\hline pGO111 (GoxPDC & $\begin{array}{l}\mathrm{Amp}^{\mathrm{r}}, \operatorname{Kan}^{\mathrm{r}} \text { (in G. thermoglucosidasius), } 3603 \mathrm{bp} \text { Dra III-EcoRV } \\
\text { fragment, blunted at the DraIII end, from pldhGO cloned into } \\
\text { the unique SwaI site of pTMO111 }\end{array}$ & This study \\
\hline pGOF111 (GoxPDC $\left.\mathrm{OPT}_{\mathrm{O}}\right)$ & $\begin{array}{l}\text { Amp }^{\mathrm{r}}, \operatorname{Kan}^{\mathrm{r}} \text { (in } G \text {. thermoglucosidasius) }, 1,887 \text { bp Not } \mathrm{I}-N o t \mathrm{I} \text { fragment, } \\
\text { containing the fully codon optimized G. oxydans PDC with the Pldh } \\
\text { upstream, cloned into the unique Not I site of pTMO111 }\end{array}$ & This study \\
\hline \multicolumn{3}{|c|}{$T^{1}$} \\
\hline LDHF & 5'-TATACCATGGGCGGGACGGGGAGCTGAGTGCTC-3' & Cripps (2009) \\
\hline LDHR & 5'-GCCGCATATGATTCATCCTCCCTCAATAT-3' & Cripps (2009) \\
\hline GOPDCpETF & 5'-GGAATTCCATATGACTTATACTGTCGG-3' & This study \\
\hline GOPDCpETR & 5'-CCGCTCGAGTCAGACGCTCTGCGG-3' & This study \\
\hline
\end{tabular}

The QIAGEN plasmid midi kit was used for large-scale plasmid preparations. DNA was sequenced using an ABI Prism 377 automated DNA sequencer and sequences were analyzed with DNAMAN (version 4.1, LynnonBioSoft). Codon usage in G. thermoglucosidasius NCIMB 11955 (with particular reference to the PDC genes from G. oxydans ) were analyzed using the web servers http://www.kazusa.or.jp/codon/cgibin/showcodon.. gi species $=1426 \&$ aa $=1 \&$ style $=\mathrm{N}$ and http://gcua.schoedl.de $/$.

\section{Polymerase chain reaction}

Polymerase chain reaction (PCR) was performed using Phusion DNA polymerase (New England Biolabs $\left.{ }^{\mathrm{TM}}\right)$. Generally, 50 ng DNA were used in a $50 \mu \mathrm{l}$ reaction volume containing $2 \mathrm{mM} \mathrm{MgCl} 2,0.125 \mu \mathrm{M}$ of each primer, $0.2 \mathrm{mM}$ of each deoxynucleoside triphosphate, and 1 U DNA polymerase. Reactions were carried out in a Hybaid Sprint thermocycler, with an initial denaturation at $94{ }^{\circ} \mathrm{C}$ for $60 \mathrm{~s}$, followed by 30 cycles of denaturation (30 s at $94{ }^{\circ} \mathrm{C}$ ), annealing (30 s), and variable elongation $\left(72{ }^{\circ} \mathrm{C}\right.$ ), where annealing temperatures and elongation times were adjusted as required. Primers are listed in Table 1. 


\section{Cloning of the G. oxydans pdc gene}

The pdc gene was amplified using genomic DNA isolated from G. oxydans DSMZ7145 using primers GoxPDCpETF and GoxPDCpETR (Table 1). The gene encoding the G. oxydans pyruvate decarboxylase was cloned into the pET28a expression vector in two parts. The $5^{\prime} 913$ bp fragment was cloned by digesting both PCR product and pET28a with NdeI and Xho I. The 779 bp 3 -fragment was first cloned into pBluescriptSK by digesting the GoxPDC PCR product with Xho I, and then excised by Xho I digestion and cloned into Xho I-digested pET28-GoxPDC- 5 '. Clones with the correct orientation of this $779 \mathrm{bp}$ fragment were identified by restriction enzyme digest of the final construct (pGO) using Sph I, and confirmed by sequencing. The nucleotide sequences of the wild type and codon-optimized pdc genes have been submitted to the EMBL-GenBank database and are available under accession numbers KF650838 and KF650839, respectively.

\section{Purification of PDC protein}

An overnight culture of pGO (Table 1) in E. coli BL21-DE3 with kanamycin was used to inoculate fresh LB broth $(1 / 100 \mathrm{ml})$ and then incubated with aeration $(120 \mathrm{rpm})$ overnight at room temperature to express the protein without IPTG induction. The cells were collected by centrifugation $(3,214 \times \mathrm{g}$ for $10 \mathrm{~min})$. BugBuster ${ }^{\mathrm{TM}}$ was used to lyse cells $(3 \mathrm{ml} / \mathrm{g}$ of wet cells) and the suspension incubated at room temperature for 20 min with shaking. After centrifugation to remove cell debris $(12,857 \times \mathrm{g}$ for $20 \mathrm{~min})$, DNaseI and RNaseA (Fermentas) were added (10 U/ml) to the lysate to reduce the viscosity and incubated at room temperature with shaking for $30 \mathrm{~min}$. The HisBind ${ }^{\mathrm{TM}}$ resin and buffer kit (Novagen) was used to purify the protein. After elution with $9 \mathrm{ml}$ imidazole buffer (100 $\mathrm{mM}$ ), the protein was dialysed against 200 volumes of buffer (50 mM MES pH 6.4) containing $1 \mathrm{mM}$ TPP and 1 $\mathrm{mM} \mathrm{MgCl} 2$. Purity was estimated by reducing sodium dodecyl sulfate polyacrylamide gel electrophoresis (SDS-PAGE) gel (12\%) and the protein concentrations determined using Bradford reagent (Bio-Rad) with bovine serum albumin as the standard (Laemmli et al. 1970).

\section{Steady state kinetics and substrate specificity}

GoxPDC activity was measured using a coupled assay with baker's yeast ADH (SigmaAldrich) as described (Conway et al. 1987), and represents a different assay to that used in the initial G. oxydans PDC characterization in the King and Cheldelin study (King et al. 1954). The enzyme was purified independently four times and kinetic measurements performed with each preparation to give the average $(n \geq 3)$ of the results shown. The reaction mixture ( 1 $\mathrm{ml}$ final volume) contained $0.25 \mathrm{mM} \mathrm{NADH}, 5 \mathrm{mM} \mathrm{MgCl} 2,0.1 \mathrm{mM}$ TPP, $5 \mathrm{mM}$ pyruvate (unless stated otherwise), and $10 \mathrm{U}$ of $\mathrm{ADH}$ in $50 \mathrm{mM}$ MES or $200 \mathrm{mM}$ Na citrate pH 6.4 or 6.0, respectively. For substrate range determination, ADH was replaced with $1 \mathrm{U} / \mathrm{ml}$ baker's yeast aldehyde dehydrogenase (ALDH, Sigma-Aldrich). $\beta$-mercaptoethanol was added to a final concentration of $3 \mathrm{mM}$ and $\mathrm{NADH}$ replaced with $\mathrm{NAD}^{+}$. Assays were performed in 100 $\mathrm{mM}$ citric acid/ $\mathrm{K}_{2} \mathrm{HPO}_{4}$ buffer $\mathrm{pH} 7.0$ (Vuralhan et al. 2005). Activities were recorded at 25 ${ }^{\circ} \mathrm{C}$ unless otherwise indicated using a Cary 50 temperature controlled spectrophotometer (Varian). In the case where aldehydes produced by the decarboxylation of certain substrates by PDC were not recognized as a substrate for ALDH, high-performance liquid

\section{http://repository.uwc.ac.za}


chromatography (HPLC) analysis was used to determine activity on that substrate. Reactions were run on a Rezex RHM monosaccharide column (Phenomonex), using $5 \mathrm{mM} \mathrm{H}_{2} \mathrm{SO}_{4}$ as mobile phase under isocratic elution $\left(0.6 \mathrm{ml} / \mathrm{min}, 40{ }^{\circ} \mathrm{C}\right)$ on a Dionex Ultimate 3000 machine. Samples $(20 \mu \mathrm{l})$ were injected by autosampler and the components detected using either a refractive index detector or a UV/ Vis photodiode array at $215 \mathrm{~nm}$. For kinetic data, initial rates were measured over the substrate range of 0.1 to $30 \mathrm{mM}$ for pyruvate or 0.1 to 50 $\mathrm{mM}$ for other 2-keto acids. Kinetic parameters were determined by nonlinear fitting of data to hyperbolic curves according to Michaelis-Menten (GraphPad Prism v. 4.00, GraphPad Software, San Diego, CA, USA). One unit of enzyme activity corresponds to the amount of enzyme that generates $1 \mu \mathrm{mol}$ of acetaldehyde per minute. $\mathrm{k}$ cat values were calculated based on the MW of the monomer with one active site.

\section{Construction of the pdc expression for transformation in G. thermoglucosidasius}

For expression of PDC in G. thermoglucosidasius, the 170-bp promoter region of the lactate dehydrogenase gene Pldh from G. thermoglucosidasius NCA1503 was cloned upstream of the Goxpdc gene. This promoter has been shown to be induced under microaerobic conditions in G. thermoglucosidasius (Cripps et al. 2009). The promoter region was amplified from pTMO49 using the LDHF and LDHR primers and cloned into pGEM-T Easy. Sequencing confirmed that no DNA base changes had occurred. The pldh was cloned into pGO (Table 1) using the Nco I and NdeI sites such that the promoter was functional for pdc expression. This construct was digested with Dra III and the ends filled in using T4 DNA polymerase (Fermentas, ThermoFisher). Digestion with Eco RV yields a 3,603 bp Dra III (blunt)-Eco RV fragment. The plasmid TMO111 was digested with Swa I and treated with rAPid $^{\mathrm{TM}}$ alkaline phosphatase (Roche) to prevent self-ligation. The Dra III (blunt)-Eco RV fragment and Swa I digested pTMO111, were ligated using T4 DNA ligase (Fermentas). Insertion at the SwaI site leaves 809 and $436 \mathrm{bp}$ of the pflB gene on either side of the ldh-pdc for recombination with its chromosomal counterpart.

The constructs were passaged through E. coli JM109 for DNA methylation prior to transformation to prevent endonuclease degradation in G. thermoglucosidasius. G. thermoglucosidasius competent cells were prepared and transformed (Cripps et al. 2009).

\section{Fermentative product profile quantification}

Cultures expressing pdc gene were grown overnight at $37^{\circ} \mathrm{C}$ for $16 \mathrm{~h}$ and $200 \mathrm{rpm}$ in LB media (E. coli) and $2 \mathrm{TY}$ media (G. thermoglucosidasius ) at $60^{\circ} \mathrm{C}$. A volume of $0.5 \mathrm{ml}$ of this culture was transferred to $10 \mathrm{ml}$ of USMYE media, contained separately, in 50 and $15 \mathrm{ml}$ screw-cap universal tubes. This effectively generated $40 \mathrm{ml}$ and $5 \mathrm{ml}$ headspaces, respectively, mimicking aerobic and microaerobic or fermentative culture conditions. These cultures were grown overnight at 37 (E. coli), 45, or $52{ }^{\circ} \mathrm{C}$ (G. thermoglucosidasius) for $16 \mathrm{~h}$ and $200 \mathrm{rpm}$ and the supernatant removed by centrifugation (2, $057 \times \mathrm{g}$ for $10 \mathrm{~min})$. Metabolite concentrations in culture supernatants were determined by HPLC (see above) and products were compared to suitable standards of known concentration and against the media in which the cultures

\section{http://repository.uwc.ac.za}


were grown. Experiments were carried out in triplicate for E. coli and at least in duplicate for G. thermoglucosidasius .

\section{Western blotting}

Rabbit anti-GoxPDC polyclonal antibodies were made by Antibodies Incorporated (Davis, CA, USA) using His-tag purified GoxPDC protein. Cells were harvested directly after fermentation by centrifugation at $3,214 \times \mathrm{g}$ for $10 \mathrm{~min}$. The cell pellet was resuspended in MES buffer pH6.5 and sonicated using five pulses of $30 \mathrm{~s}$ each. Cell debris was removed by centrifugation $(15,682 \times \mathrm{g}$ for $20 \mathrm{~min}$ ), and the supernatant decanted. Protein concentrations were determined by Bradford assay. Forty micrograms of total protein was loaded for each sample and run on a $12 \%$ SDS-PAGE gel. Protein was transferred from the gel to Biotrace ${ }^{\mathrm{TM}} \mathrm{PVDF}$ membrane by semidry blotting. For signal detection, the anti-rabbit Super Signal West Femto Chemiluminescent Substrate (Pierce) kit was used and the signal visualized using a chemiluminescent camera.

\section{Results}

\section{Amino acid sequence considerations in the G. oxydans PDC}

The cloned and sequenced GoxPDC gene differed from the published genome sequence (NC_006677.1) (Prust et al. 2005) at 22 positions, resulting in 5 amino acid changes (Y163F, S207N, A209T, I469M, and D517E) but no frame shifts or deleterious events. The sequence alignment (Fig. 1) indicated that none of the affected residues have been shown to be directly involved in catalysis, substrate, or co-factor binding. Most changes are conservative (F163, N207, and E517) and/or are located distantly from the active site (F163, N2O7, T209, and E517). Met469 is, however, located in a region of the enzyme which may be sensitive to changes. It is positioned adjacent to Glu468, important in catalytic activity; Ile467, involved in substrate recognition; and Ile471, crucial for substrate positioning (Prust et al. 2005; Pohl et al. 1998; Siegert et al. 2005). However, equivalent residues in other PDCs have not been associated with catalysis or substrate recognition (Fig. 1). Phe163 (Fig. 1) is an interesting change, as it is occupied by a tyrosine in all the PDCs (including the G. oxydans NC_006677.1 PDC, except for SvePDC). GoxPDC, unlike ZpaPDC and ApaPDC, also contains an extra six amino acid loop from position 498-503 (EESGKY), which is similar to positions 503-508 in ZmoPDC (DSGAGK), but the residues are not conserved. As the encoding gene was amplified using a polymerase with $3^{\prime}-5^{\prime}$ exonuclease activity and the differences were consistent in several independent clones, we infer that the changes represent natural variations in the GoxPDC and are not artifacts of the cloning procedure.

The protein sequence demonstrates all the features typical of ThDP-binding enzymes including the conserved ThDP binding motif GDGS-XXX-NN as well as several conserved residues required for substrate binding and catalysis (indicated in Fig. 1). It does, however, lack a cysteine residue equivalent to Cys221 in ScePDC, as shown for all the bacterial PDCs, thought to be involved in allosteric substrate activation ( $\mathrm{Lu}$ et al. 2000).

\section{http://repository.uwc.ac.za}




\section{Kinetic characterization of the GoxPDC enzyme}

GoxPDC was purified to homogeneity by affinity chromatography, and the estimated molecular weight of the protein, at $\pm 60 \mathrm{kDa}$ (Fig. 2), corresponds well to the theoretical molecular mass of $60.8 \mathrm{kDa}$. The predicted $\mathrm{pI}$ value is 6.o. Conventional enzyme characterization was performed using pyruvate as a substrate (kinetic data for GoxPDC are summarized in Table 2). The KM value for pyruvate was found to be in the range of those determined for other PDCs from Gram-negative bacteria assayed under similar conditions. The enzyme also displayed a \pm 20 -fold decrease in the $\mathrm{KM}$ for pyruvate with a decrease in $\mathrm{pH}$ from 7 to 5 , without an equivalent change in the catalytic rate ( $\mathrm{k}$ cat showed an approximate twofold decrease). This is in line with previous observations in related enzymes (Raj et al. 2002; Siegert et al. 2005) and supports the interpretation that PDCs require a protonated residue for efficient binding of the substrate, in which the ionizable group is thought to be the aminopyrimidine ring of the ThDP coenzyme (Meyer et al. 2010). The GoxPDC enzyme displayed normal Michaelis-Menten kinetics with pyruvate as the substrate and was not subject to allosteric substrate activation as has been reported for PDCs from plants, yeasts, and the SvePDC (Konig et al. 2009). The GoxPDC has a lower catalytic rate than ApaPDC but the catalytic efficiencies were similar to those reported for ZmoPDC and SvePDC. The pH optimum of GoxPDC was determined to lie between 4.5 and 5.0, similar to ApaPDC and slightly lower than for other PDCs from Gramnegative bacteria (Fig. 3; Gocke et al. 2009). The temperature optimum of GoxPDC was between 50 and $55{ }^{\circ} \mathrm{C}$. Thermal inactivation studies demonstrated that the enzyme was stable at the experimental $\mathrm{T}_{\mathrm{Opt}}$, with no loss of activity after an hour of incubation. However, at temperatures $\geq 60{ }^{\circ} \mathrm{C}$, moderate to rapid loss of activity was recorded, retaining $30 \%$ of the initial activity at $65{ }^{\circ} \mathrm{C}$ after an hour of incubation (Fig. 4). These data demonstrate that GoxPDC thermostability is equivalent to the Gram-negative homologs. 
ZmoPDC

GdiPDC

ZpaPDC

ApaPDC

GOXPDC

ZmaPDC

ScePDC

SvePDC

Consensus

ZmoPDC

GdiPDC

ZpaPDC

ApaPDC

GOXPDC

ZmaPDC

ScePDC

SvePDC

Consensus

ZmoPDC

GdiPDC

ZpaPDC

ApaPDC

GOXPDC

ZmaPDC

SCePDC

SvePDC

Consensus

ZMOPDC

GdiPDC

ZpaPDC

ApaPDC

GOXPDC

ZmaPDC

ScePDC

SvePDC

Consensus

ZmoPDC

GdiPDC

ZpaPDC

ApaPDC

GOXPDC

ZmaPDC

ScePDC

SvePDC

Consensus

ZmoPDC

GdiPDC

ZpaPDC

ApaPDC

GoxPDC

ZmaPDC

ScePDC

SvePDC

Consensus

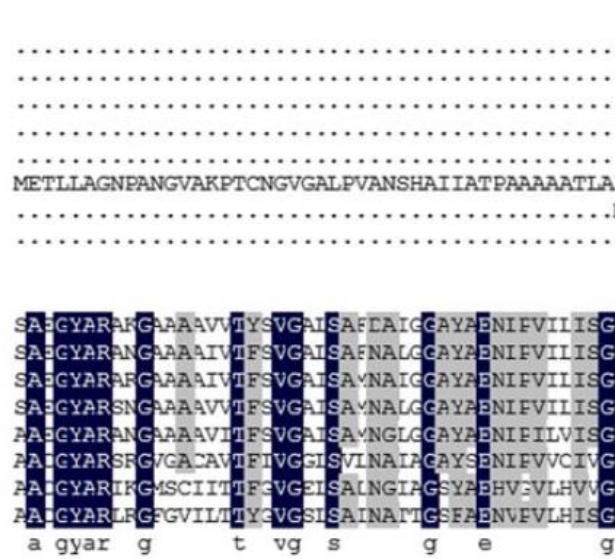

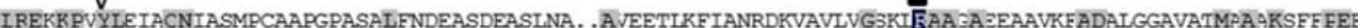
IREKK PAYLEIACNVAGAPCVRPGGIDALISPPAPDEASLKA. .AVDAAIAFIEQRGSVIMLVGSRIFAA ZA 2AQAVAIADALGCAVTTMPA AKSFF FED

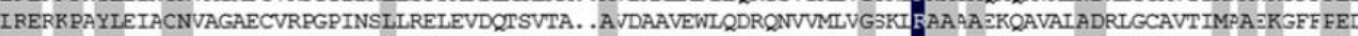
IRERKPAYIDIACNIASEPCVRPGPVSSLISEPEIDHTSLKA. . AVDATVALLKNRPAPVIILIGSKIRAA VALAATETI ADKLPCAVTIMPA AKGFF FED IREKK PAFLEIACNISAAPCVRPGPVSSLHAHPRPDEASLKA. . ALDESISFLNKTNKVAILVGKKIFAA TA LKETVEI ADKLGCPVTVMPA AKSYF FET IRESKPVYISVS CNLAGLSHPTFSRDPVPMFISPRLSNKANLEYAVEAAADFLNKAVKPVMVGGPKIRVAKA REAFAAVADASGYPFAVMEAAKGLVFEH YVTCRPVYLGLPANLVDLNVPAKLIQTFIDMSLKPNDAESEKEVIDTILALVKDAKNPVILAIA CCSRHDVKAETKKLIDITQFPAFVTPNGKGSIDEQ. KYQLPGYIELPVDIVSKEIEIDEMKPLNLTMRSNEKTLEKFVNDVKEMVASSKGQH . . ILADYEVIGAKAEKELEGFINEAKIPVNTLSIGKTAVSES .

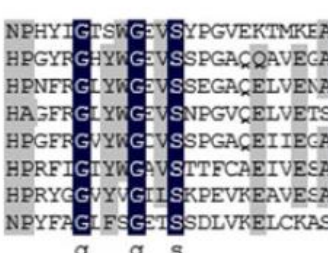

90

KKAAPADPSAPLVNAEIARQVEALITPNTTVIZETCISWFNA PRMIKI PNGQRVEYEN C्CWGE AAPT - APT IENSVAA AAEPN . . . . APLTNDEMTRQIQSLITSDTTLIAET ATSDE....AGLTNDEIVRHINALITSNTTLVRETC ADPSK. . . . PLSNDEMT, ROINELVDGNTTLF FET CI 作 NAAVPASTPLKQEWMNNQLGNFLQEGDVVI . . . E PTDAKLTQDRYFRQMEAFLKPNDVLVG. . . . .

\section{IIm} ig CYAIPAVIC

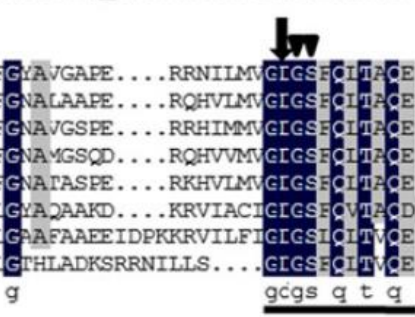

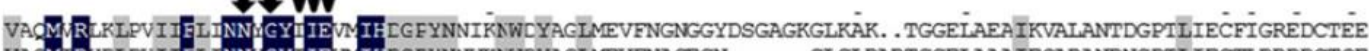

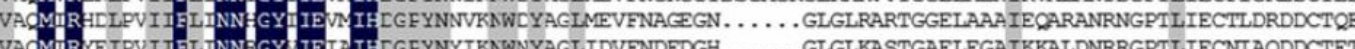

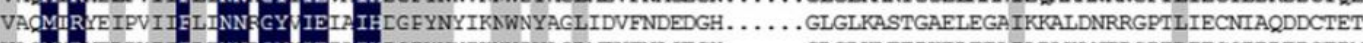

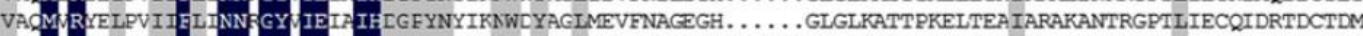
CGFYNYICAWDYAAIMQCFNQGVPGEESGKYGLGLHATTGAEIAEA IAKAKKNTRGPTLIECKLDRTDCTKT

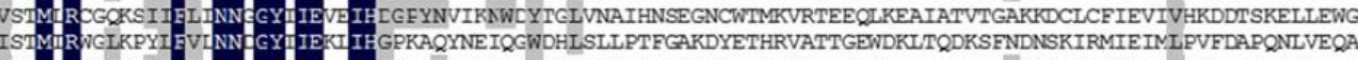

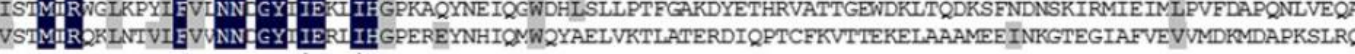

\section{gy ie ih}

LVKWGKRVAAANSRRPVNKI

LVTWGKRVAAANARQPRAG.

LIAWGKRVAATNSRKPQA. .

LVOWGRKVASTNARKTTLA.

LVEWGKAVAAANSRKPQSV.

SRVS. . . . AANSRPPNPQ.

KLTAATNARQ ........

EASLFSSQNNY........ 
Fig. 1 Multiple sequence alignment of the protein sequences from selected PDC proteins: GdiPDC, G. diazotrophicus (YP_001600462.1); GoxPDC, G. oxydans; ZpaPDC, Z palmae (AF474145_1); ApaPDC, A. pasteuriamus (AF368435_1); ZmoPDC, Z. mobilis (YP_163095.1); ZmaPDC, Z. mays (P28516.1), ScePDC, S. cerevisiae (EGA85775.1); SiePDC, S. ventriculi (AF354297_1). The alignment was generated using the "full alignment" feature in DNAman with default setting. Residues shaded in black are $100 \%$ conserved while those in grey are $75 \%$ conserved. The underlined region shows the conserved ThDP-binding motif and triangles indicate those residues which bind ThDP. Arrows indicate $\mathrm{Mg}^{2+}$ binding residues. Circles indicate residues which line the catalytic pocket and are thought to play a role in catalysis. Asterisk indicates the residue involved in substrate specificity. The star shows a residue thought to be needed for positioning of the substrate for catalysis. The square indicates the arginine residue involved in substrate activation of ScePDC and SvePDC. The open triangle shows the position of the unique phenylalanine residue in GoxPDC

The following substrates were shown by HPLC analysis to be decarboxylated by GoxPDC; 2ketopropanoate (pyruvate), 2-ketobutanoate, 2-ketopentanoate, 2-keto-4-methylpentanoate, and 4-hydroxy-phenyl-pyruvate. Calculated specific activities were $32 \mathrm{U} / \mathrm{mg}$ for 2-keto-butanoate, $1.2 \mathrm{U} / \mathrm{mg}$ for2-keto-pentanoate, and $0.2 \mathrm{U} / \mathrm{mg}$ for 2-keto-4-methylpentanoate. No activity was recorded on 3-phenyl-2-oxopropanoate, benzoyl formate, 4-hydroxy-phenyl pyruvate, and indole-3-pyruvate.

\section{Native pde (GoxPDCWT) expression in E. coli and G. thermoglucosidasius}

The expression of GoxPDCWT in E. coli produced $0.5 \pm 0.005 \mathrm{~g} / \mathrm{g}$ ethanol per gram of glucose consumed under fermentative conditions, substantially higher than the control (DH5a-pTMO111) which produced only $0.1 \pm 0.01 \mathrm{~g} / \mathrm{g}$. Cell densities were of the same order of magnitude, demonstrating that the higher ethanol concentrations were not simply the result of higher biomass levels in GoxPDC-positive strains. It is noted that these elevated ethanol yields were achieved in the absence of a recombinant adh II, which has previously been shown to be essential for enhanced ethanol production in E. coli strains expressing ZmoPDC (Lawford et al. 1991). This constitutes the first report demonstrating ethanol production as a direct result of the functional expression of only a pdc gene in E. coli (Liu et al. 2005; Talarico et al. 2005; Lowe et al. 1992).

Expression in G. thermoglucosidasius under microaerobic conditions did not result in ethanol production more than the control strain (Fig. 5). RT-PCR confirmed that the gene was transcribed (data not shown); however, no soluble protein could be detected by Western blotting for cultures grown at $45{ }^{\circ} \mathrm{C}$ (Fig. 6) and no PDC activity was detected using cell free extracts from the same cultures. Together, these data suggest a failure at the level of translation, possibly with the generation of misfolded protein which would be targeted for intracellular proteolysis.

\section{Assessing codon usage and predicting a gene sequence for harmonization of GoxPDC expression in G. thermoglucosidasius}

A relatively new concept, termed codon harmonization (Angov et al. 2008, 2011a, b), was proposed as a technique to assist protein folding during heterologous expression. Co-don harmonization, as opposed to other codon optimization strategies, involves mimicking the

\section{http://repository.uwc.ac.za}


translation rates of the native host in a heterologous strain. The translation rate is predominantly determined by codon usage frequencies, where the presence of infrequently used codons forces a reduction of the translation rate, allowing the protein being translated to fold in phases. Both the frequency and positioning of infrequently used codons is critical for protein folding (Clarke et al. 2008).

An analysis of the codon usage frequencies in GoxPDC for expression in G. thermoglucosidasius, E. coli, and G. oxydans was conducted (Table 3, Fig. 7). There are five codons which are rarely used in G. oxydans, the native host, on e of which (CGA) is al so rarely used in G.thermoglucosidasius. However, in G. thermoglucosidasius, 20 codons in the GoxPDC gene (CCC and CTC) are recognized as rare, which are frequently used ( $>20 \%)$ in the native host. It is thought that the inclusion of so many rare codons when expressing the gene in G. thermoglucosidasius, is detrimental to correct folding of the protein (Kane et al. 1995; Kim et al. 2006; Rosano et al. 2009). Similarly, in E. coli, the CTC and CGA codons are also rare. However, unlike in G. thermoglucosidasius, the CCC codon is infrequently used (Table 3). Based on the rare codon analysis, E. coli is expected to be a more suitable expression host for the WT GoxPDC relative to G. thermoglucosidasius. This was the case experimentally; however, the temperature had to be reduced $\left(25^{\circ} \mathrm{C}\right)$ to enable soluble expression of the GoxPDC protein in E. coli.

In order to codon harmonize the GoxPDC gene for G. thermoglucosidasius expression, 416 bp changes (348 codon substitutions) were made to the wild-type gene sequence so as to match the usage frequencies found in the native host for every codon position while maintaining the amino acid composition of the wild-type protein. Figure 7 shows a 20 amino acid section of the protein to demonstrate how the harmonization was performed.

This harmonization strategy was chosen to demonstrate whether the naturally evolved translation frequency alone would enable correct folding of the protein in G. thermoglucosidasius, without the need to calculate link/end segments (Angov et al. 2008; Thanaraj et al. 1996). 
Fig. 2 A denaturing SDS-PAGE gel showing purified GoxPDC protein. 1 Molecular weight marker (\#SM0671), 2 HIS-tag purified GoxPDC protein. The GoxDC protein was approximately to $59 \mathrm{kDa}$ in size

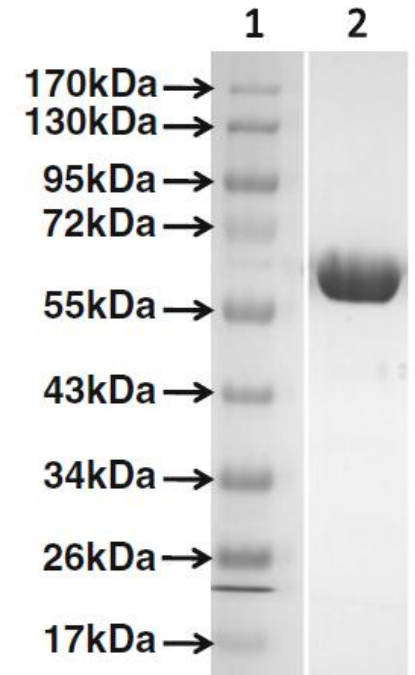

\begin{tabular}{|c|c|c|c|c|c|c|c|}
\hline PDC & $K_{M}(\mathrm{mM})$ & $\begin{array}{l}\text { Specific activity } \\
\text { in }(\mathrm{U} / \mathrm{mg})\end{array}$ & $k_{\text {cat }}\left(\mathrm{s}^{-1}\right)$ & $\begin{array}{l}k_{\mathrm{cat}} / K_{M} \\
\left(\mathrm{M}^{-1} \mathrm{~s}^{-1}\right)\end{array}$ & $\begin{array}{l}T_{\text {opt }} \\
\left({ }^{\circ} \mathrm{C}\right)\end{array}$ & $\mathrm{pH}_{\mathrm{opt}}$ & $T_{1 / 2}$ at ${ }^{\circ} \mathrm{C}$ \\
\hline \multirow[t]{2}{*}{ GoxPDC $_{R}$} & $\begin{array}{l}0.12(5.0) \pm 0.005 \\
1.2(6.5) \pm 0.2\end{array}$ & $\begin{array}{l}57(5.0) \\
47(6.5)\end{array}$ & $\begin{array}{l}57(5.0) \\
47(6.5)\end{array}$ & $\begin{array}{l}4.75 \times 10^{5}(5.0) \\
3.6 \times 10^{4}(6.5)\end{array}$ & \multirow[t]{2}{*}{53} & \multirow[t]{2}{*}{$4.5-5.0$} & \multirow[t]{2}{*}{$10 \mathrm{~min}$ at $65^{\circ} \mathrm{C}$} \\
\hline & $2.8(7.0) \pm 0.4$ & $125(7.0)$ & $125(7.0)$ & $4.2 \times 10^{4}(7.0)$ & & & \\
\hline GoxPDC $_{N}$ & $0.74(6.0)$ & $4.4(6.0)^{\mathrm{g}}$ & $\mathrm{N} / \mathrm{A}$ & $\mathrm{N} / \mathrm{A}$ & N/A & 6.0 & f \\
\hline ApaPDC & $2.8(6.5)^{\mathrm{a}} / 0.39(5.0)^{\mathrm{e}}$ & $110(6.5)^{\mathrm{a}} / 97(5.0)^{\mathrm{e}}$ & $341-508^{\mathrm{e}}$ & N/A & $65^{\mathrm{a}}$ & $3.5-6.5^{\mathrm{a}}$ & $24 \min$ at $70^{\circ} \mathrm{C}^{\mathrm{a}}$ \\
\hline ZpaPDC & $2.5(6.5)^{\mathrm{a}} / 0.24(6.0)^{\mathrm{e}}$ & $116(6.5)^{\mathrm{a}} / 130(6.0)^{\mathrm{e}}$ & $341-508^{\mathrm{e}}$ & $\mathrm{N} / \mathrm{A}$ & $55^{\mathrm{a}}$ & $7.0^{\mathrm{a}}$ & $24 \min$ at $60^{\circ} \mathrm{C}^{\mathrm{a}}$ \\
\hline ZmoPDC & $1.3(6.5)^{\mathrm{a}} / 0.31(6.0)^{\mathrm{b}} / 1.1^{\mathrm{c}}$ & $120(6.5)^{\mathrm{a}} / 120^{\mathrm{c}}$ & $150(6.0)^{\mathrm{b}} / 486(6.5)^{\mathrm{c}}$ & $4.8 \times 10^{5}(6.0)^{\mathrm{b}} / 4.4 \times 10^{5}(6.5)^{\mathrm{c}}$ & $60^{\mathrm{a}}$ & $6.0-6.5^{\mathrm{a}}$ & $30 \mathrm{~min}$ at $60^{\circ} \mathrm{C}^{\mathrm{a}}$ \\
\hline SvePDC & $13^{\mathrm{d}}$ & $103^{\mathrm{d}}$ & $412^{\mathrm{d}}$ & $3.2 \times 10^{4 \mathrm{~d}} / 0.87 \times 10^{4}(7.0)$ & $\mathrm{N} / \mathrm{A}$ & $6.3-6.7^{\mathrm{d}}$ & $30 \mathrm{~min}$ at $50^{\circ} \mathrm{C}$ \\
\hline
\end{tabular}

For all experiments done on $\mathrm{GoxPDC}_{\mathrm{R}}, n \geq 3$. Values in brackets indicate $\mathrm{pH}$

${ }_{N}$ native, ${ }_{R}$ recombinant, $f$ stable for $5 \mathrm{~min}$ at $55^{\circ} \mathrm{C}$ but completely inactivated by incubating for $3 \mathrm{~min}$ at $80^{\circ} \mathrm{C}, g$ crude extract

${ }^{a}$ Gocke et al. (2009)

${ }^{\mathrm{b}}$ Meyer et al. (2010)

${ }^{\mathrm{c}}$ Siegert et al. (2005)

${ }^{\mathrm{d}}$ Lowe et al. (1992)

${ }^{\mathrm{e}}$ Raj et al. (2002)

\section{Expression of GoxPDCOPT in G. thermoglucosidasius}

Comparative expression of the wild-type (GoxPDCWT) and codon harmonized (GoxPDCOPT) GoxPDC in G. thermoglucosidasius TM89 was evaluated at 45 and $52{ }^{\circ} \mathrm{C}$ (Fig. 5). Expression of GoxPDCOPT at $45^{\circ} \mathrm{C}$ produced $0.35 \pm 0.04$ ethanol per gram of glucose consumed, compared to $0.26 \pm 0.04 \mathrm{~g} / \mathrm{g}$ for TM89 alone or $0.24 \pm 0.02 \mathrm{~g} / \mathrm{g}$ for GoxPDCWT (Fig. 5). This result clearly demonstrates that translational discord was, at least in part, a significant limitation to the functional expression of GoxPDC in G. thermoglucosidasius. However, at $52{ }^{\circ} \mathrm{C}$ strains expressing either GoxPDCWT $(0.26 \pm 0.01 \mathrm{~g} / \mathrm{g})$ or GoxPDCOPT $(0.25 \pm 0.04 \mathrm{~g} / \mathrm{g})$ produced lower ethanol yields than the control TM89 (0.32 $\pm 0.05 \mathrm{~g} / \mathrm{g}$; Fig. 5). We speculate that the reduced performance of TM89 when expressing either the unmodified or codon-harmonized GoxPDC at $52{ }^{\circ} \mathrm{C}$ may be due to the metabolic load

\section{http://repository.uwc.ac.za}


imposed by the presence of the shuttle vector and/or the metabolic load imposed by misfolded PDC protein (proteotoxic stress).

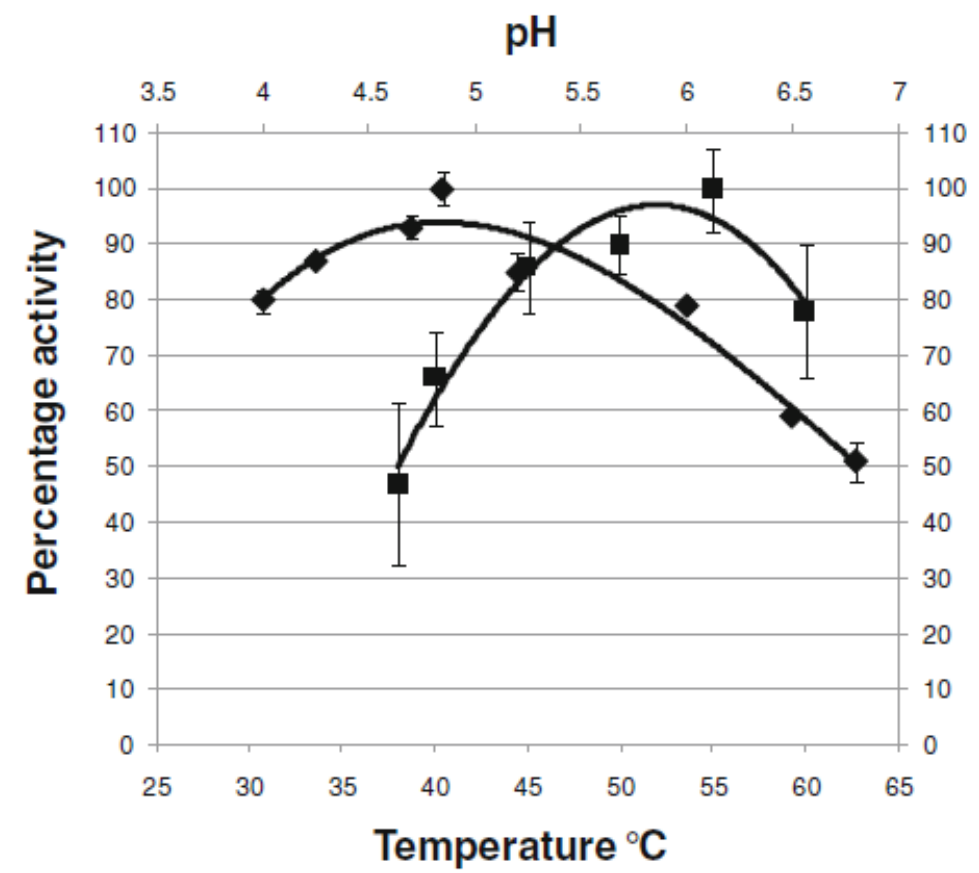

Fig. 3 Effect of $\mathrm{pH}$ and temperature (in degree Celsius) on the activity of GoxPDC (black diamond) when using pyruvate as substrate. For all data points, $n \geq 3$. The assay buffer used was $100 \mathrm{mM} \mathrm{Na}_{2} \mathrm{HPO}_{4} /$ citrate buffer. The $100 \%$ activity was analogous to a specific activity of $72 \mathrm{U} / \mathrm{mg}$ for $T_{\text {opt }}$ and $160 \mathrm{U} / \mathrm{mg}$ for $\mathrm{pH}_{\text {opt }}$

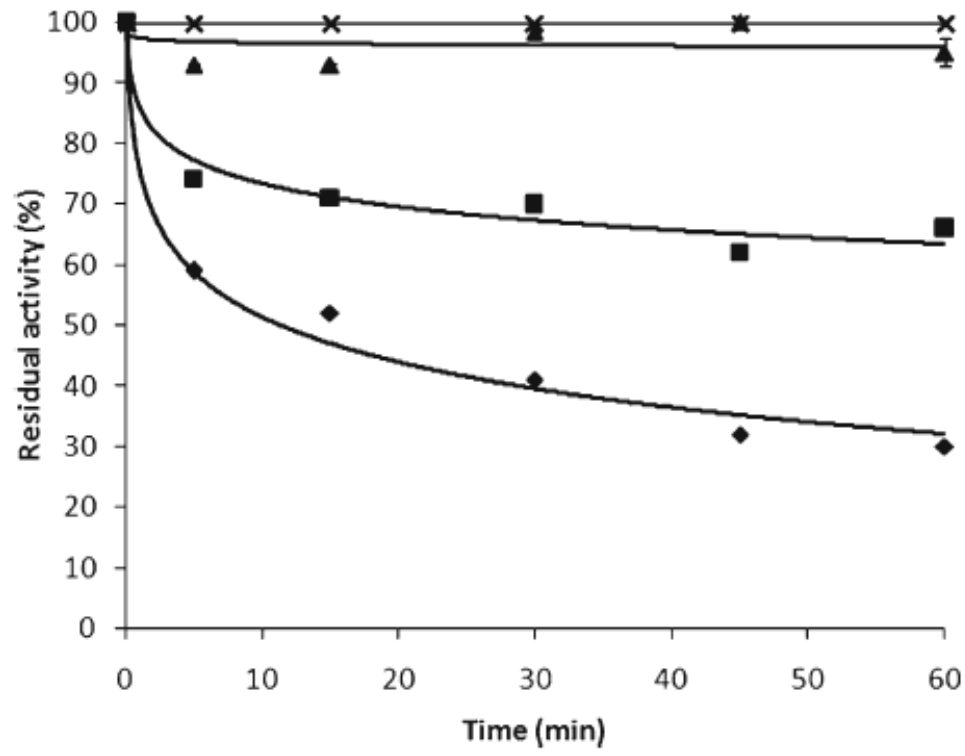

Fig. 4 Thermal inactivation profile of GoxPDC at $25^{\circ} \mathrm{C}$ (multiplication symbol), $55^{\circ} \mathrm{C}$ (black triangle), $60^{\circ} \mathrm{C}$ (black square), and $65^{\circ} \mathrm{C}$ (in black diamond). Activity is expressed as a percentage of that at time zero in the standard assay at $25^{\circ} \mathrm{C}$. The activity at $100 \%$ correlates to a specific activity of $26 \mathrm{U} / \mathrm{mg}$. Assays were performed in $50 \mathrm{mM}$ MES buffer at $\mathrm{pH} 6.5$ 


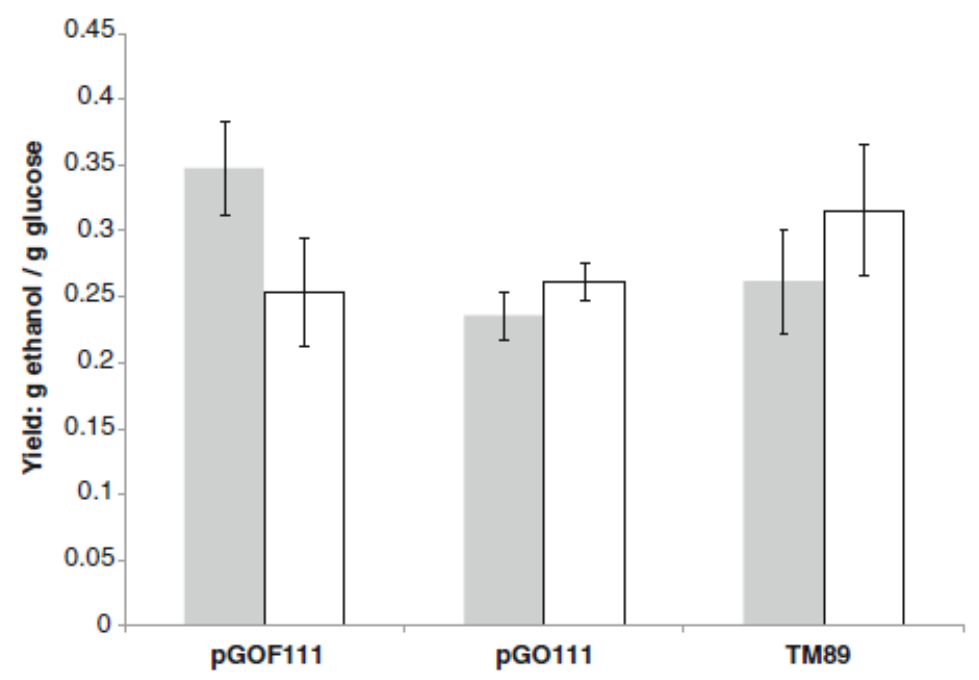

Fig. 5 Comparison of the yield of ethanol produced per gram of glucose consumed during 10/15 model fermentations in G. thermoglucosidasius. Grey bars represent fermentations performed at $45{ }^{\circ} \mathrm{C}$ and white bars $52^{\circ} \mathrm{C}$. The data represents an average of three independent fermentations (batches of medium) with three repeats of each culture in each fermentations after $48 \mathrm{H}$ at the given temperature

Intracellular PDC activity was assayed from GoxPDCOPT-G. thermoglucosidasius cultures grown at $45{ }^{\circ} \mathrm{C}$ and $52{ }^{\circ} \mathrm{C}$. A specific activity of $0.22 \mathrm{U} / \mathrm{mg}$ was determined for GoxPDCOPT cultures grown at $45{ }^{\circ} \mathrm{C}$, consistent with the observed phenotype. No detectable activity could be demonstrated for the control and GoxPDCWT cultures under similar conditions. No PDC activity was detectable in GoxPDCOPT-G. thermoglucosidasius cultures grown at $52{ }^{\circ} \mathrm{C}$. Furthermore, through Western blot analysis, a GoxPDC signal was only detectable in soluble protein extracts from $\mathrm{G}$. thermoglucosidasius cultures expressing GoxPDCOPT at $45{ }^{\circ} \mathrm{C}$ (Fig. 6). Extracts from cells grown at $52{ }^{\circ} \mathrm{C}$ (GoxPDCWT, GoxPDCOPT, and control cultures) were reproducibly negative. Given that in vitro thermostability does not necessarily equate to in vivo stability, the lack of improved ethanol production at $52{ }^{\circ} \mathrm{C}$ is not unexpected. These results, taken together, indicate that although codon harmonization enhanced the expression of GoxPDC in G. thermoglucosidasius TM89 at 45 ${ }^{\circ} \mathrm{C}$, a second limitation, probably thermally related, prevents functional enzyme accumulation at higher temperatures. The lack of detectable protein by Western blotting either indicates that a second limitation is present at the transcription- translation interface or that the protein produced is extremely unstable and the resultant aggregates or proteolysis products are not suitable for antibody binding.

Nevertheless, the increased ethanol yield at $45{ }^{\circ} \mathrm{C}$ represents a significant improvement in comparison to other engineered thermophiles (Cripps et al. 2009; Shaw et al. 2008). It has been demonstrated that effective partitioning of carbon into biosynthesis and fermentation is critical in achieving optimal production of ethanol under fermentative conditions (Underwood et al. 2002b). Typically, G. thermoglucosidasius TM89 
fermentations are characterized by the production of formate (average of $40.5 \pm 7.2 \mathrm{mM}$ after $48 \mathrm{~h}$ at $45^{\circ} \mathrm{C}$ ) and acetate with ethanol (Cripps et al. 2009). However, it was noted that for TM89-GoxPDCOPT fermentations at $45{ }^{\circ} \mathrm{C}$, no formate was produced but low level $( \pm 185$ $\mu \mathrm{M})$ fumarate accumulation was detected in culture supernatants. This may be due to a reduced metabolic flux through pfl where the active GoxPDCOPT may outcompete the pfl enzyme for pyruvate (Orencio-Trejo et al. 2008; Tolan et al. 1987; Feldmann et al. 1989; Underwood et al. 2002a).

\section{Discussion}

The pyruvate decarboxylase from the acetic acid bacterium G. oxydans has been described in this study. The substrate recognition and decarboxylation range of the enzyme is similar to that of the other four Gram-negative PDCs identified to date, showing a preference for short-chain aliphatic 2-keto acids (Gocke et al. 2009). The value of $\mathrm{k}$ cat/ $\mathrm{K} \mathrm{M}$ for pyruvate compared to those for 2-ketobutanoate and 2-ketopentanoate, the nearest analogs, and the retention of Ile468, thought to be involved in substrate specificity, suggests that this enzyme favors pyruvate as its physiological substrate (Pohl et al. 1998; Gocke et al. 2009). The GoxPDC kinetics are also similar to the other Gram-negative bacterial PDCs, displaying the same $\mathrm{pH}$ dependent increase in $\mathrm{k}_{\mathrm{cat}} / \mathrm{K}_{\mathrm{M}}$ while catalytic efficiency ( $\mathrm{k}_{\mathrm{cat}}$ ) remaining largely unchanged.

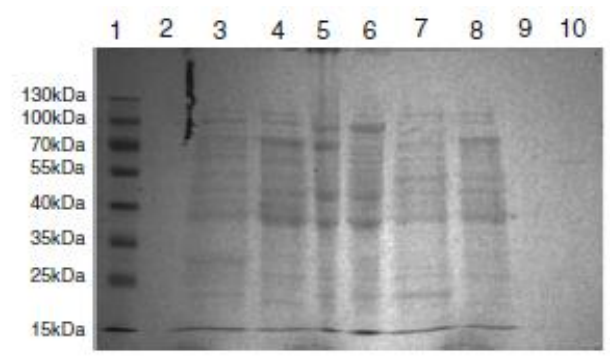

Fig. 6 SDS-PAGE and Western blots of cell extracts from $G$. thermoglucosidasius TM89, containing either empty vector pTMO111 (5 and 8 ) or pGO111 (GoxPDC $\mathrm{WT}_{\mathrm{WT}} ; 4$ and 7), or pGOF 111 (GoxPDC OPT; $_{\text {; }}$

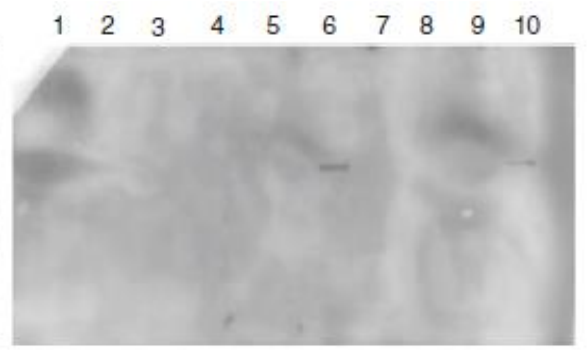

3 and 6$)$. Cultures were grown at either $45^{\circ} \mathrm{C}(6,7$, and 8$)$ or $52^{\circ} \mathrm{C}(3,4$, and 5), respectively. Purified GoxPDC protein served as positive control (10). Lanes 2 and 9 are empty

Table 3 The correspondence of rare codons ( $<10 \%$ usage) for PDCs which have been expressed in G. thermoglucosidasius and in E. coli, between their native host and G. thermoglucosidasius

\begin{tabular}{|c|c|c|c|c|}
\hline & $\begin{array}{l}\text { All codons with }<10 \% \text { usage } \\
\text { in the native host (number of } \\
\text { codons in respective } p d c \text { genes) }\end{array}$ & $\begin{array}{l}\text { All codons with }<10 \% \text { usage } \\
\text { in G. thermoglucosidasius } \\
\text { (amino acid position) }\end{array}$ & $\begin{array}{l}\text { All codons with }<10 \% \\
\text { usage in } E \text {. coli } \\
\text { (amino acid position) }\end{array}$ & $\begin{array}{l}\% \text { codon usage for selected } \\
\text { codons in their native host }\end{array}$ \\
\hline ZmoPDC & CTC (11) & $\begin{array}{l}\text { CTC }(2,18,30,56,164,174,215, \\
236,306,320,348,362,400, \\
436,567,568), \text { CCC }(174,320) \\
\text { AGT }(2,56,362)\end{array}$ & $\begin{array}{l}\text { CGG }(12), \text { CTC }(18,30, \\
164,215,236,306,348, \\
400,436,567,568,569)\end{array}$ & CCC $10-20 \%$, AGT $10-20 \%$ \\
\hline ZpaPDC & $\begin{array}{l}\text { CTA (4), TTG (3), ACA (3), CTC } \\
\text { (3), GTG (2), CTT (2), GCG (2), } \\
\text { TCA (2), CCC (1), AGT (1), } \\
\text { GGA (1), TCG (1), AAG (1), } \\
\text { CCA (1) }\end{array}$ & $\begin{array}{c}\text { CTC }(35,187,517), \text { CCC (356), CTA } \\
(12,155,231,509), \text { AGT (193) }\end{array}$ & $\begin{array}{c}\text { СТC }(35,187,517), \text { CTA } \\
(12,155,231,509),\end{array}$ & N/A \\
\hline GoxPDC & $\begin{array}{l}\operatorname{ACT}(2), \operatorname{CGA}(1), \operatorname{TCT}(1) \\
\text { TCA (1) }\end{array}$ & $\begin{array}{c}\text { CGA }(12), \text { CTC }(30,33,84,95, \\
164,206,226,305,431,505, \\
531,536,545), \text { CCC }(174,239 \\
251,255,309,348,396)\end{array}$ & $\begin{array}{l}\text { CGA (12), CTC }(30,33, \\
84,95,164,206,226, \\
305,431,505,531 \\
536,545)\end{array}$ & CTC $>20 \%$, CCC $>20 \%$ \\
\hline
\end{tabular}


Despite being an elusive enzyme in the bacterial kingdom, PDCs are sought after enzymes for the generation of ethanologens, and the engineering of a PDC-expressing pathway in fermentative bacteria is now a well-established procedure to achieve increased ethanol yields from mesophilic organisms (Taylor et al. 2008, Thompson et al. 2008, Talarico et al. 2005, Bi et al. 2009, Tolan et al. 1987, Ingram et al. 1987, Correa et al. 2011). In this study, expression of GoxPDC in E. coli resulted in a fivefold ethanol production increase, with a final yield of $0.5 \mathrm{~g} / \mathrm{g}$, similar to the best results reported for other recombinant E. coli strains, and moreover, without the co-expression of a heterologous adh (Ohta et al. 1991).

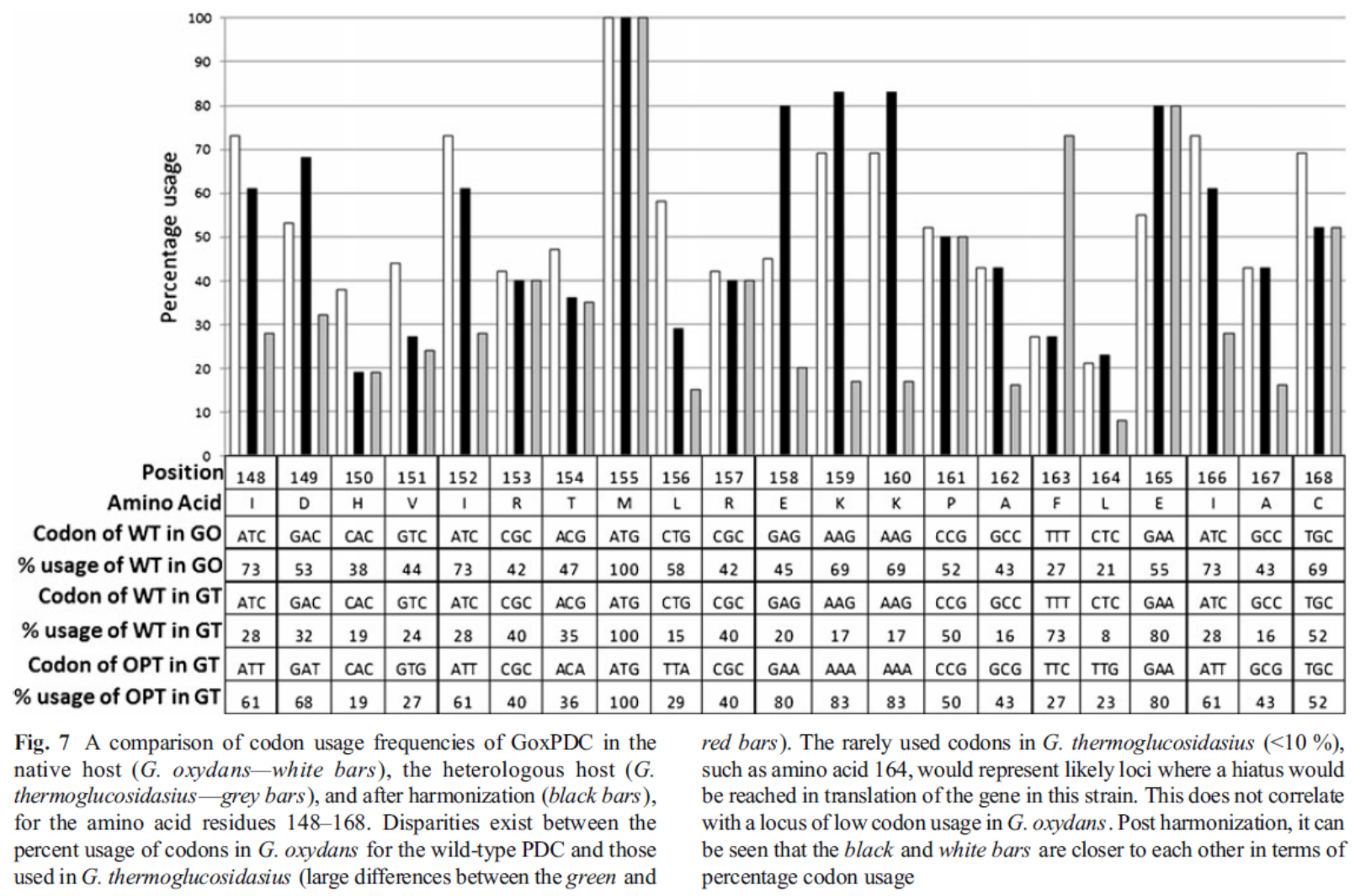

In G. thermoglucosidasius expression of the codon, harmonized GoxPDC resulted in a significant improvement in ethanol production. This represents the first account of in vivo PDC-mediated ethanol production in a Gram positive organism, and in a thermophile. While expression of several PDCs has been demonstrated in Geobacillus and Bacillus megaterium, none of these studies could demonstrate increased cellular ethanol production (Taylor et al. 2008, Thompson et al. 2008, Talarico et al. 2001). Considering that G. thermoglucosidasius is currently employed in a commercially viable bioethanol technology, this finding could represent a significant advancement in the engineering of a thermophilic ethanologen. The upregulation of pyruvate dehydrogenase and subsequent conversion of acetyl-CoA to acetaldehyde is stoichiometrically equivalent to a PDC intervention, and is the engineering strategy employed for the bioethanol process strain G. thermoglucosidasius TM242 (Cripps et al. 2009). It would be of value therefore for future studies to compare the performance of PDC- vs PDH-engineered G. thermoglucosidasius

\section{http://repository.uwc.ac.za}


in a pfl-negative background, in order to maximize the flux of pyruvate to ethanol. However, despite the significance of these findings, PDC- mediated ethanol production in this study was only possible at a maximum temperature of $48{ }^{\circ} \mathrm{C}$, and therefore the lack of PDC thermostability continues to limit the viability of the PDC route for a thermophilic commercial process.

It has long been known that codon usage differences during heterologous protein expression can result in low expression or formation of insoluble aggregates. The tendency has been to replace the rare codons in the protein of interest for codons used more frequently by the expression host. However, only recently has the suggestion been made that the frequency and positioning of infrequently used codons is critical for protein folding, and that the standard codon optimization approach is flawed. Instead, the principal of codon harmonization (Angov et al. 2008) involving the substitution of synonymous codons from the heterologous host such that the codon usage frequency, positioning, and therefore rhythm of translation follows that of the native host, was recently proposed. Codon harmonization has been exclusively applied to expression in E. coli , therefore this study provides further evidence that codon harmonization may provide a general strategy for improving the expression of soluble, functional proteins in a wide range of bacterial hosts. Precedence for this already exists if one analyses the expression of two other Gram-negative PDCs (ZmoPDC and ZpaPDC) in G. thermoglucosidasius . Production of soluble ZmoPDC in cell free extracts of G. thermoglucosidasius grown at 52, 54, 56, and 58 ${ }^{\circ} \mathrm{C}$ was observed to decrease with increased temperature, and PDC activity was undetectable above $52{ }^{\circ} \mathrm{C}$ (Thompson et al. 2008). For ZpaPDC, activity was absent at growth temperatures above $45{ }^{\circ} \mathrm{C}$ (Taylor et al. 2008). An analysis of the codon usage pattern of these PDCs expressed in G. thermoglucosidasius revealed that they have a higher coincidence of both frequency-of-usage and positioning of rare codons for expression in G. thermoglucosidasius (Table 3), which does not represent a large deviation from the frequency in the native host. Therefore, this provides further support for the codon harmonization concept, and this correlation may be responsible for the reported variations in PDC-expression efficiency in G. thermoglucosidasius: ZmoPDC $>$ ZpaPDC $>$ GoxPDC.

Despite the improvement in GoxPDC expression as a result of codon harmonization, there are still other factors which continue to play a major role in the functionality of the enzyme at higher growth temperatures. When correctly folded the GoxPDC protein displays relatively high thermostability when assayed in vitro. However, this does not necessarily translate to the ability to fold correctly at elevated temperatures, offering a possible explanation for the apparent failure of functional expression at $52{ }^{\circ} \mathrm{C}$, unlike ZmoPDC when expressed in the same host (Thompson et al. 2008). We suggest that although codon harmonization contributes to the correct folding of a nascent protein during translation of the mRNA, it cannot necessarily compensate for the kinetics involved in protein folding in temperature ranges outside those for which the protein had been selected for or evolved under. The further stabilization of the enzyme therefore represents an area of future improvement for the use of PDC in engineering superior homo-ethanolic pathways in G. thermoglucosidasius .

\section{http://repository.uwc.ac.za}


The significant role that codon harmonization played in the correct processing of GoxPDC protein when expressed in G. thermoglucosidasius serves to reiterate the importance of codon usage in heterologous protein expression. This study represents the first account of improved expression of a protein of mesophilic origin in a thermophilic host using this technique, and demonstrates the potential benefits for microbial biotechnology. Due to its metabolic versatility, Geobacillus is a suitable platform organism for the synthesis of additional industrial products. In this light, codon harmonization should play a pivotal role in enabling and improving its development and in expanding its biotechnological repertoire.

\section{Acknowledgments}

The G. oxydans strain was a kind gift from the Institute for Wine Biotechnology (IWBT) at the University of Stellenbosch. This work was supported by the National Research Foundation of South Africa. 


\section{References}

Angov E (2011) Codon usage: nature's roadmap to expression and folding of proteins. Biotechnol J 66:650-659

Angov E, Hillier CJ, Kincaid RL, Lyon JA (2008) Heterologous protein expression is enhanced by harmonizing the codon usage frequencies of the target gene with those of the expression host. PLoS ONE 3:e2189

Angov E, Legler PM, Mease RM (2011) Adjustment of codon usage frequencies by codon harmonization improves protein expression and folding. Methods Mol Biol 705:1-13

Bi C, Zhang X, Ingram LO, Preston JF (2009) Genetic engineering of Enterobacter asburiae strain JDR-1 for efficient production of ethanol from hemicellulose hydrolysates. Appl Environ Microbiol 75:5743-5749

Bongers RS, Hoefnagel MH, Kleerebezem M (2005) High-level acetaldehyde production in Lactococcus lactis by metabolic engineering. Appl Environ Microbiol 71:1109-1113

Clarke TF IV, Clark PL (2008) Rare codons cluster. PLoS ONE 3:e3412 Conway T, Osman YA, Konnan JI, Hoffmann EM, Ingram LO (1987) Promoter and nucleotide sequences of the Zymomonas mobilis pyruvate decarboxylase. J Bacteriol 169:949-954

Correa A, Oppezzo P (2011) Tuning different expression parameters to achieve soluble recombinant proteins in E. coli: advantages of high-throughput screening. Biotechnol $\mathrm{J}$ 66:715-730

Cripps RE, Eley K, Leak DJ, Rudd B, Taylor M, Todd M, Boakes S, Martin S, Atkinson T (2009) Metabolic engineering of Geobacillus thermoglucosidasius for high yield ethanol production. Metab Eng 11:398-408

Feldmann S, Sprenger GA, Sham H (1989) Ethanol production from xylose with a pyruvateformate-lyase mutant of Klebsiella planticola carrying a pyruvate-decarboxylase gene from Zymomonas mobilis. Appl Microbiol Biotechnol 31:152-157

Gocke D, Graf T, Brosi H, Frindi-Wosch I, Walter L (2009) Comparative characterisation of thiamin diphosphate-dependent decarboxylases. J Mol Catal B Enzym 61:30-35

Gold RS, Meagher MM, Tong S, Hutkins RW, Conway T (1996) Cloning and expression of the Zymomonas mobilis "production of ethanol" genes in Lactobacillus casei. Curr Microbiol 33:256- 260

Gupta A, Singh VK, Qazi GN, Kumar A (2001) Gluconobacter oxydans: its biotechnological applications. J Mol Microbiol Biotechnol 33: 445-456

Gustafsson C, Govindarajan S, Minshull J (2004) Codon bias and heterologous protein expression. Trends Biotechnol 22:346-353

Ingram LO, Conway T, Clark DP, Sewell GW, Preston JF (1987) Genetic engineering of ethanol production in Escherichia coli. Appl Environ Microbiol 53:2420-2425

Kaczowka SJ, Reuter CJ, Talarico LA, Maupin-Furlow JA (2005) Recombinant production of Zymomonas mobilis pyruvate decar-boxylase in the haloarchaeon Haloferax volcanii. Archaea 15: 327-334

Kane JF (1995) Effects of rare codon clusters on high-level expression of heterologous proteins in Escherichia coli. Curr Opin Biotechnol 65: 494-500

Kim S, Lee SB (2006) Rare codon clusters at $5^{\prime}$-end influence heterologous expression of archaeal gene in Escherichia coli. Protein Expr Purif 50:49-57 
King TE, Cheldelin VH (1954) Pyruvic carboxylase of Acetobacter suboxydans . J Biol Chem 208:821-831

Konig S (1998) Subunit structure, function and organisation of pyruvate decarboxylases from various organisms. Biochim Biophys Acta 1385:271-286

Konig S, Spinka M, Kutter S (2009) Allosteric activation of pyruvate decarboxylases. A neverending story? J Mol Catal B Enzym 61: 100-110

Kotze AA, Tuffin IM, Deane SM, Rawlings DE (2006) Cloning and characterization of the chromosomal arsenic resistance genes from Acidithiobacillus caldus and enhanced arsenic resistance on conjugal transfer of ars genes located on transposon TnAtcArs. Microbiology 152:3551-3560

Laemmli UK (1970) Cleavage of structural proteins during the assembly of the head of bacteriophage T4. Nature 227:680-685

Lawford HG, Rousseau JD (1991) Ethanol production by recombinant Escherichia coli carrying genes from Zymomonas mobilis. Appl Biochem Biotechnol 28-29:221-236

Liu S, Dien BS, Cotta MA (2005) Functional expression of bacterial Zymobacter palmae pyruvate decarboxylase gene in Lactococcus lactis . Curr Microbiol 50:324-328

Liu S, Nichols NN, Dien BS, Cotta MA (2006) Metabolic engineering of a Lactobacillus plantarum double ldh knockout strain for enhanced ethanol production. J Ind Microbiol Biotechnol 33:1-7

Liu S, Dien BS, Nichols NN, Bischoff KM, Hughes SR, Cotta MA (2007) Coexpression of pyruvate decarboxylase and alcohol dehydrogenase genes in Lactobacillus brevis. FEMS Microbiol Lett 274: 291-297

Lowe SE, Zeikus JG (1992) Purification and characterization of pyruvate decarboxylase from Sarcina ventriculi. J Gen Microbiol 138:803-807

Lu G, Dobritzsch D, Baumann S, Schneider G, Konig S (2000) The structural basis of substrate activation in yeast pyruvate decarboxylase. A crystallographic and kinetic study. Eur J Biochem 267:861- 868

Meyer D, Neumann P, Parthier C, Friedemann R, Nemeria N, Jordan F, Tittmann K (2010) Double duty for a conserved glutamate in pyruvate decarboxylase: evidence of the participation in stereoelectronically controlled decarboxylation and in protonation of the nascent carbanion/enamine intermediate. Biochemistry 49: 8197-8212

Ohta K, Beall DS, Mejia JP, Shanmugam KT, Ingram LO (1991) Genetic improvement of Escherichia coli for ethanol production: chromosomal integration of Zymomonas mobilis genes encoding pyruvate decarboxylase and alcohol dehydrogenase II. Appl Environ Microbiol 57:893-900

Orencio-Trejo M, Flores N, Escalante A, Hernandez-Chavez G, Bolivar F, Gosset G, Martinez A (2008) Metabolic regulation analysis of an ethanologenic Escherichia coli strain based on RT-PCR and enzymatic activities. Biotechnol Biofuels 1:8

Peters B, Junker A, Brauer K, Mühlthaler B, Kostner D, Mientus M, Liebl W, Ehrenreich A (2012) Deletion of pyruvate decarboxylase by a new method for efficient markerless gene deletions in Gluconobacter oxydans. Appl Microbiol Biotechnol 97:2521-2530

Pohl M, Mesch K, Rodenbrock A, Kula MR (1995) Stability investigations on the pyruvate decarboxylase from Zymomonas mobilis. Biotechnol Appl Biochem 22:95-105

\section{http://repository.uwc.ac.za}


Pohl M, Siegert P, Mesch K, Bruhn H, Grotzinger J (1998) Active site mutants of pyruvate decarboxylase from Zymomonas mobilis-a site-directed mutagenesis study of L112, I472, I476, E473, and N482. Eur J Biochem 257:538-546

Prust C, Hoffmeister M, Liesegang H, Wiezer A, Fricke WF, Ehrenreich A, Gottschalk G, Deppenmeier U (2005) Complete genome sequence of the acetic acid bacterium Gluconobacter oxydans. Nat Biotechnol 23:195-200

Raj KC, Ingram LO, Maupin-Furlow JA (2001) Pyruvate decarboxylase: a key enzyme for the oxidative metabolism of lactic acid by Acetobacter pasteurianus. Arch Microbiol 176:443-451

Raj KC, Talarico LA, Ingram LO, Maupin-Furlow JA (2002) Cloning and characterization of the Zymobacter palmae pyruvate decarboxylase gene (pdc) and comparison to bacterial homologues. Appl Environ Microbiol 68:2869-2876

Rosano GL, Ceccarelli EA (2009) Rare codon content affects the solubility of recombinant proteins in a codon bias-adjusted Escherichia coli strain. Microb Cell Fact 8:41

Sambrook J, Fritsch EF, Maniatis T (1989) Molecular cloning: a laboratory manual. Cold Spring Harbour Press, Cold Spring Harbor, NY

Shaw AJ, Podkaminer KK, Desai SG, Bardsley JS, Rogers SR, Thorne PG, Hogsett DA, Lynd LR (2008) Metabolic engineering of a thermophilic bacterium to produce ethanol at high yield. Proc Natl Acad Sci 105:13769-13774

Siegert P, McLeish MJ, Baumann M, Iding H, Kneen MM, Kenyon GL, Pohl M (2005) Exchanging the substrate specificities of pyruvate decarboxylase from Zymomonas mobilis and benzoylformate decarboxylase from Pseudomonas putida. Protein Eng Des Sel 18:345- 357

Talarico LA, Ingram LO, Maupin-Furlow JA (2001) Production of the Gram-positive Sarcina ventriculi pyruvate decarboxylase in Escherichia coli. Microbiology 147:2425-2435

Talarico LA, Gil MA, Yomano LP, Ingram LO, Maupin-Furlow JA (2005) Construction and expression of an ethanol production operon in Gram-positive bacteria. Microbiology 151:4023-4031

Taylor MP, Esteban CD, Leak DJ (2008) Development of a versatile shuttle vector for gene expression in Geobacillus spp. Plasmid 60: 45-52

Taylor MP, Eley KL, Martin S, Tuffin MI, Burton SG, Cowan DA (2009) Thermophilic ethanologenesis: future prospects for second-generation bioethanol production. Trends Biotechnol 27:398-405

Thanaraj TA, Argos P (1996) Protein secondary structural types are differentially coded on messenger RNA. Protein Sci 5:1973-1983

Thompson AH, Studholme DJ, Green EM, Leak DJ (2008) Heterologous expression of pyruvate decarboxylase in Geobacillus thermoglucosidasius. Biotechnol Lett 30:1359-1365

Tolan JS, Finn RK (1987) Fermentation of D-xylose to ethanol by genetically modified Klebsiella planticola. Appl Environ Microbiol 53:2039-2044

Underwood SA, Buszko ML, Shanmugam KT, Ingram LO (2002a) Flux through citrate synthase limits the growth of ethanologenic Escherichia coli KO11 during xylose fermentation. Appl Environ Microbiol 68:1071-1081 
Underwood SA, Zhou S, Causey TB, Yomano LP, Shanmugam KT, Ingram LO (2002b) Genetic changes to optimize carbon partitioning between ethanol and biosynthesis in ethanologenic Escherichia coli. Appl Environ Microbiol 68:6263-6272

Vuralhan Z, Luttik MA, Tai SL, Boer VM, Morais MA, Schipper D, Almering MJ, Kotter P, Dickinson JR, Daran JM, Pronk JT (2005) Physiological characterization of the ARO10-dependent, broad- substrate-specificity 2-oxo acid decarboxylase activity of Saccharomyces cerevisiae. Appl Environ Microbiol 71:3276-3284 